\title{
Vloga geografije pri interdisciplinarnem načrtovanju regionalnega razvoja
}

\author{
Lučka Lorber \\ Dr., Oddelek za geografijo, Pedagoška fakulteta, Univerza v Mariboru, \\ Koroška cesta 160, 2000 Maribor, Slovenija \\ e-mail: lucka.lorber@uni-mb.si
}

\section{Izvleček}

Razvojni procesi so integralni in jih lahko razumemo in evalviramo le z interdisciplinarnim pristopom. Značilnost geografske vede je njena kompleksnost v proučevanju prostora. Vloga in pomen geografije pri načrtovanju regionalnega razvoja v spremenjenih družbeno - gospodarskih razmerah je predvsem v sodelovanju z ostalimi znanstvenimi disciplinami pri zagotavljanju skladnega regionalnega razvoja.

Ključne besede: regionalni razvoj, regionalno povezovanje, trajnostni razvoj, dinamiziranje gospodarstva, uravnotežen ekonomski razvoj, interdisciplinarno načrtovanje

\section{The Role of Geography in Interdisciplinary Planning of Regional Development}

\begin{abstract}
The characteristic of the science of geography is its complexity in the study of space. Regional development processes are integral and we can understand and evaluate them through interdisciplinary approaches. The role and significance of geography in planning regional development in changed social - economic conditions is in cooperation with the remaining scientific disciplines in assuring comformable regional development.
\end{abstract}

Key words: regional development, regional integration, sustainable development, dynamism in economy, balanced economic development, interdisciplinary planning 


\section{EVROPSKA DIMENZIJA PROSTORSKEGA RAZVOJA}

Prepletanje procesov, ki jih narekuje globalizacija sveta posega v vso sfero človekovega življenja in ustvarja nove odnose med prostorskimi enotami. Gospodarska razvitost omogoča vključevanje v sodobne integracijske procese in razvoj posameznih regij. Globalne gospodarske povezave, tehnološki razvoj in politične spremembe zadnjih let so sprožile spremembe tudi v evropski prostorski strukturi. Vse močnejša evropska integracija je narekovala oblikovanje vizije o evropskem celostnem prostoru. Kot nasprotje tendencam centralizma se je razvilo poudarjanje potrebe regionalne prostorske organiziranosti Evrope kot modela decentralizacije oz. policentričnega razvojnega vzorca. Poudarjanje regionalne raznolikosti, zavest o nezamenljivi identiteti kulture, ljudi in prostora ter socioekonomskih posebnosti sta postali pozitivna usmeritev za novo oblikovanje prostorskih struktur.

Odločitev o oblikovanju enotnega trga Evropske unije je zahtevala nujno zmanjševanje razvojnih razlik med evropskimi regijami. Prednostni cilji so zagotoviti podporo gospodarsko zaostalim področjem in vključevanje gospodarstva $\mathrm{v}$ zagotavljanje regionalnega razvoja.

Od preko 370 milijonov prebivalcev na območju, ki pokriva 3,2 milij. $\mathrm{km}^{2}$ in z letnim bruto domačim proizvodom (BDP) 9216 milijard eurov je Evropska Unija ena od največjih in gospodarsko najmočnejših regij sveta (European Spatial Development Perspective, 1999). Ne glede na uspešne ekonomske kazalce, se regionalna neskladja v Evropski uniji povečujejo. Vzrokov je več. Strategija evropske prostorske razvojne perspektive je definirala tri ključne cilje prostorskega razvoja:

- Gospodarska in socialna kohezija.

- Ohranjanje naravnih virov in kulturne dediščine.

- Uravnotežena konkurenčnost evropskega ozemlja.

Zastavljene cilje, ki bi naj zagotavljali uravnotežen razvoj, je potrebno spremljati istočasno v vseh regijah EU na državni, regionalni in lokalni ravni in so tako tudi za Slovenijo kot pridruženo članico EU obvezujoči (Slika 1).

$\mathrm{Na}$ dolgoročne prostorske razvojne težnje $\mathrm{v}$ EU vplivajo predvsem trije dejavniki:

- progresivna gospodarska integracija in s tem povezano vse večje sodelovanje med državami članicami,

- naraščajoč pomen lokalnih in regionalnih skupnosti ter njihove vloge $\mathrm{v}$ prostorskem razvoju in

- pričakovana širitev EU in razvoj tesnejših odnosov z njenimi sosedami. 
Slika 1: Lokalno - regionalno - nacionalno-mednarodno povezovanje

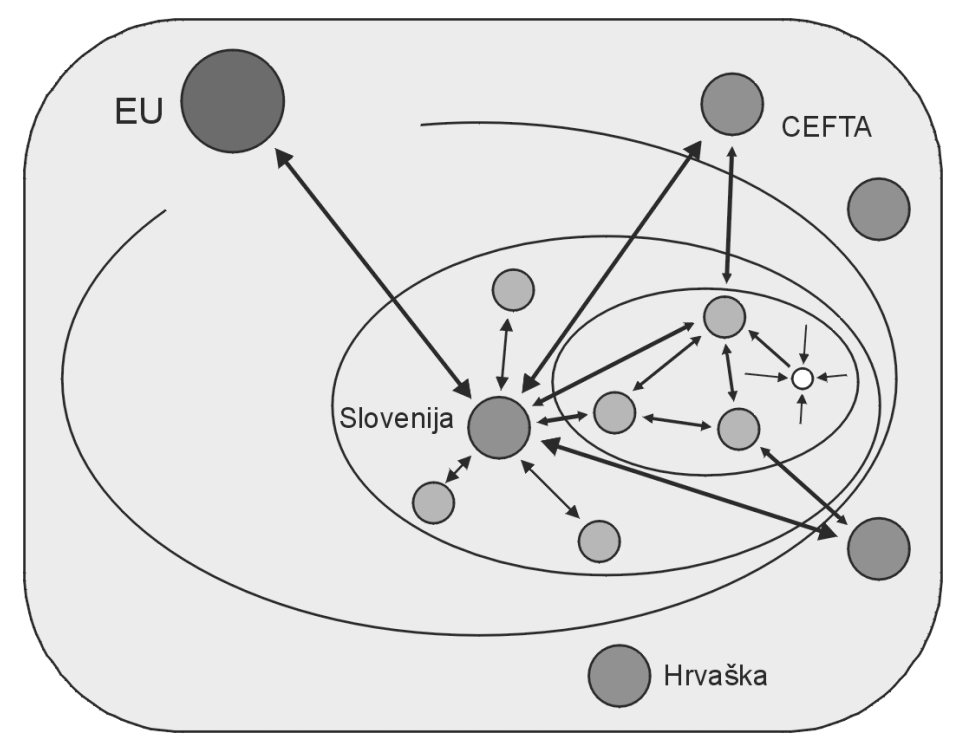

Te tri razvojne dejavnike je potrebno postaviti za ozadje globalnega gospodarskega in tehnološkega razvoja. Če bodo pravilno uporabljeni, bo s tem zagotovljen okvir za večjo kohezijo evropskega ozemlja.

\section{INTEGRIRAN PROSTORSKI RAZVOJ NAREKUJE TRANSNACIONALNO POVEZOVANJE IN MEDNARODNO SODELOVANJE}

Spremenjen geografsko - prometni položaj Slovenije omogoča gospodarsko sodelovanje $\mathrm{z}$ ekonomsko najrazvitejšimi državami, sodelovanje $\mathrm{z}$ najzahtevnejšim trgom blaga, delovne sile in kapitala. Krepi se sodelovanje s post socialističnimi (tranzicijskimi) državami vzhodne Evrope in vedno bolj se odpira trg južne Evrope. Ključna razvojna naloga je poiskati vse regionalne vire, ki jih Slovenija premore za vzpodbujanje čim višje stopnje konkurenčnosti slovenskega gospodarstva na mednarodnem trgu.

Oblikovanje skupnega evropskega prostora predvideva ekonomsko in kulturno povezovanje regij (Slika 2). Zaradi potreb, ki jih narekuje integracijski proces, je Evropska komisija pristopila k oblikovanju evropskih programov, ki bodo definirali strategijo nadaljnjega razvoja. 
Slika 2: Evropske regije

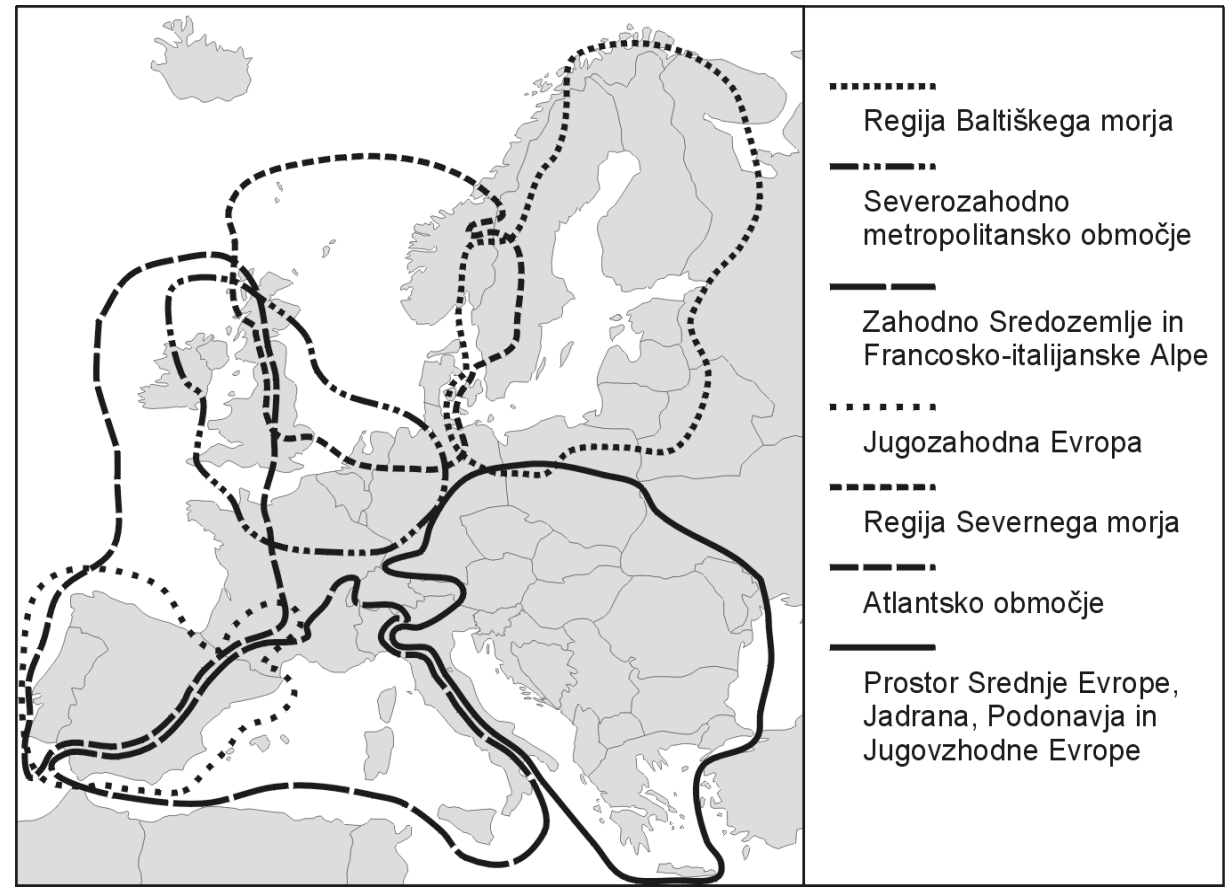

Vir: Evropska komisija, GD XVI

Krepitev strukturno šibkejših obmejnih območij Evropske unije, izboljšanje čezmejnih življenjskih in delovnih pogojev na območjih, ki so na različnih stopnjah razvoja, predstavlja velik izziv. Uskladiti je potrebno cilje razvoja, ravnotežja in varstva. Politika, usmerjena izključno v uravnoteženost, bi vodila k slabljenju gospodarsko močnejših regij in hkrati povečanju odvisnosti manj uspešnih območij. Sam razvoj pa bi dal prednost poglabljanju regionalnih neskladij. Po drugi strani pa prevelik poudarek na ohranjanju obstoječega, prinaša tveganje, da bi prišlo do stagnacije, ker bi s tem morda upočasnili razvojne težnje.

Pokrajine kot druga stopnja lokalne samouprave v Sloveniji bodo pomembno vplivale na krepitev čezmejnega sodelovanja. Danes se pojavljajo velike težave, saj sosednje države ne najdejo primernega sogovornika ali partnerja pri posameznih projektih. Večina čezmejnih projektov, ki potekajo na regijski ravni, pogosto niso izvedeni, ker regije nimajo ustreznih pristojnosti odločanja. 


\section{POKRAJINSKA UREDITEV SLOVENIJE KOT POGOJ PRI ZAGOTAVLJANJU URAVNOTEŽENEGA RAZVOJA}

V času priprav Slovenije na vključitev v evropske integracije in pri oblikovanju slovenskih regij je potrebno upoštevati prostorske strukture sodobnega evropskega razvoja. Slovenski nacionalni interes je opredeliti prostorsko organiziranost, ki bo zagotavljala uravnotežen gospodarski razvoj celotnega slovenskega prostora in bo zagotovila njen enakopravni gospodarski razvoj v mednarodni skupnosti. (Kongres lokalnih in regionalnih oblasti pri Svetu Evrope o stanju lokalne in regionalne demokracije v Sloveniji,maj 2001). Gospodarsko in prostorsko integriranje v Evropsko unijo sta v Sloveniji mišljena kot procesa, ki pomenita razvojno moč.

Občutne razlike v gospodarskem razvoju slovenskih pokrajin se še poglabljajo. Najrazvitejša je Osrednjeslovenska (Ljubljanska) regija, ki je po letu 1991 še okrepila svoj položaj. Razvojne trende, ki so značilni za postindustrijsko družbo, zasledimo samo v Osrednje slovenski in Obalno-kraški regiji. Za slovenskim povprečjem najbolj zaostajajo Podravska, Pomurska in Spodnjeposavska regija (Slika 3, 4).

Slika 3: BDP na prebivalca in deleži BDP po sektorjih (leto 2000)

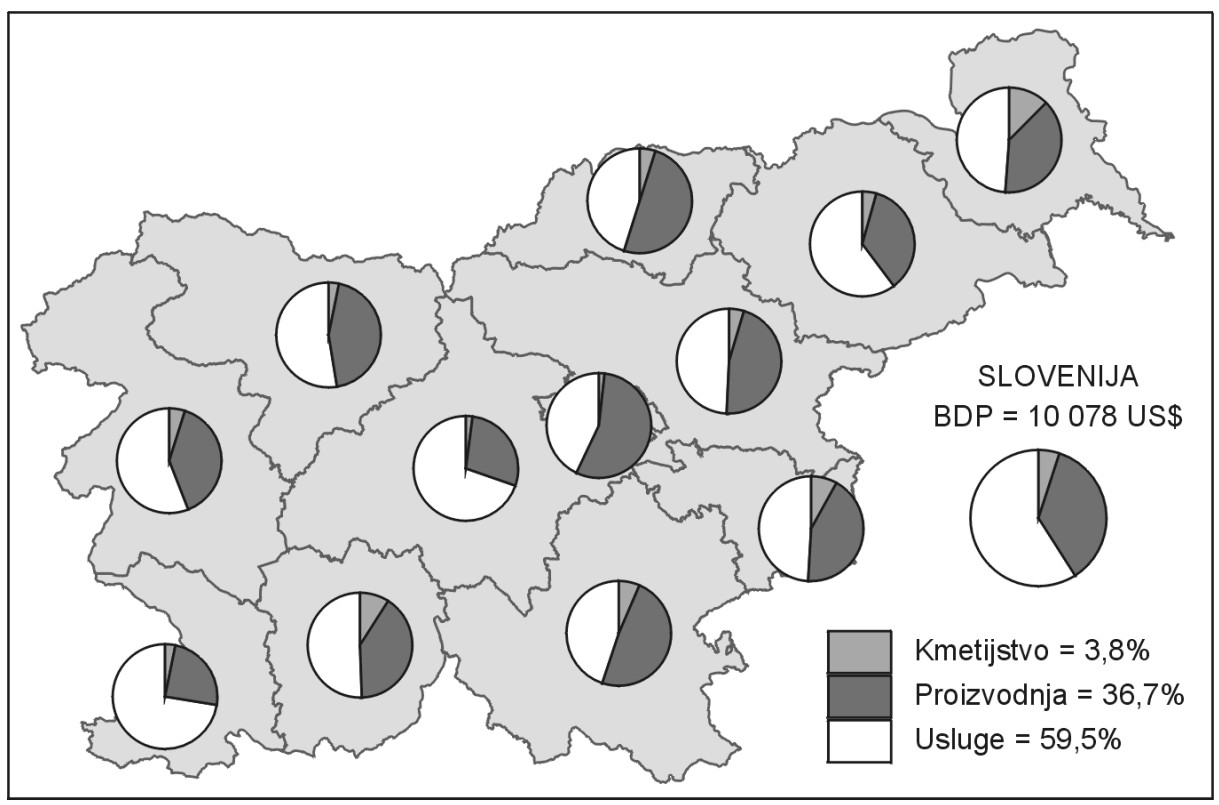

Vir: SURS 
Slika 4: Gibanje števila prebivalcev v obdobju 1990-1995-2000

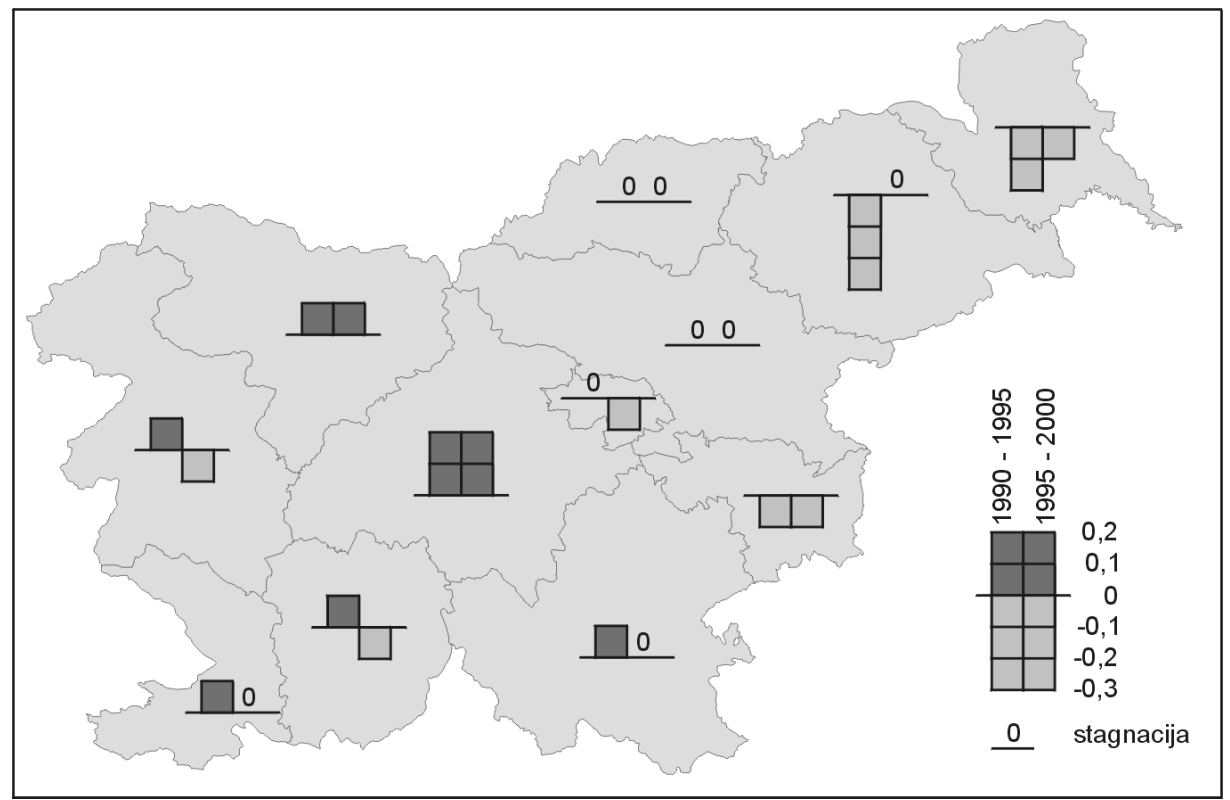

Vir: SURS

Slovenija se je opredelila za ustanovitev pokrajin in s tem se je sprožil začetek procesa decentralizacije in policentričnega uravnoteženega regionalnega razvoja (Zakon o pokrajinah, delovno gradivo, vlada RS, december 2001). Iskanje optimalne teritorialne členitve Slovenije na pokrajine pomeni istočasno tudi določanje pristojnosti ekonomsko - materialnih vprašanj, ki pomenijo tudi osnovo za odločanje o regionalnem razvoju. To je vitalnega pomena za nadaljnji razvoj slovenskih pokrajin in njihovo enakopravno vključevanje na skupni trg ter pomeni nujnost za zagotavljanje kvalitete življenja posameznika.

Velikokrat se zmotno primerja statistične regije s pokrajinami, čeprav so cilji popolnoma drugačni. Pri statističnih regijah gre predvsem za tehnične okvire za zajemanje statistični podatkov za potrebe Evropske unije in možnost kandidiranja za sredstva iz strukturnih skladov EU (Prašnikar, A., 2001). Pokrajine pa se ustanavljajo z namenom, da se zagotovi uravnoteženi gospodarski, socialni in okoljski razvoj slovenskega prostora.

Velik problem predstavljajo v Sloveniji tudi razvojne razlike med mesti oz. urbaniziranimi območji in ruralnim podeželjem. Na eni strani so območja, ki imajo velike gospodarske, kulturne in prostorske potenciale in na drugo strani so območja, ki se spopadajo s problemom gospodarske stagnacije in ne- 
ugodne demografske strukture. Ekonomski upad večine podeželjskih območij predstavlja resno oviro v procesu pokrajinske členitve Slovenije (Slika 5).

\section{Slika 5: Smeri notranjih migracij (leto 2000)}

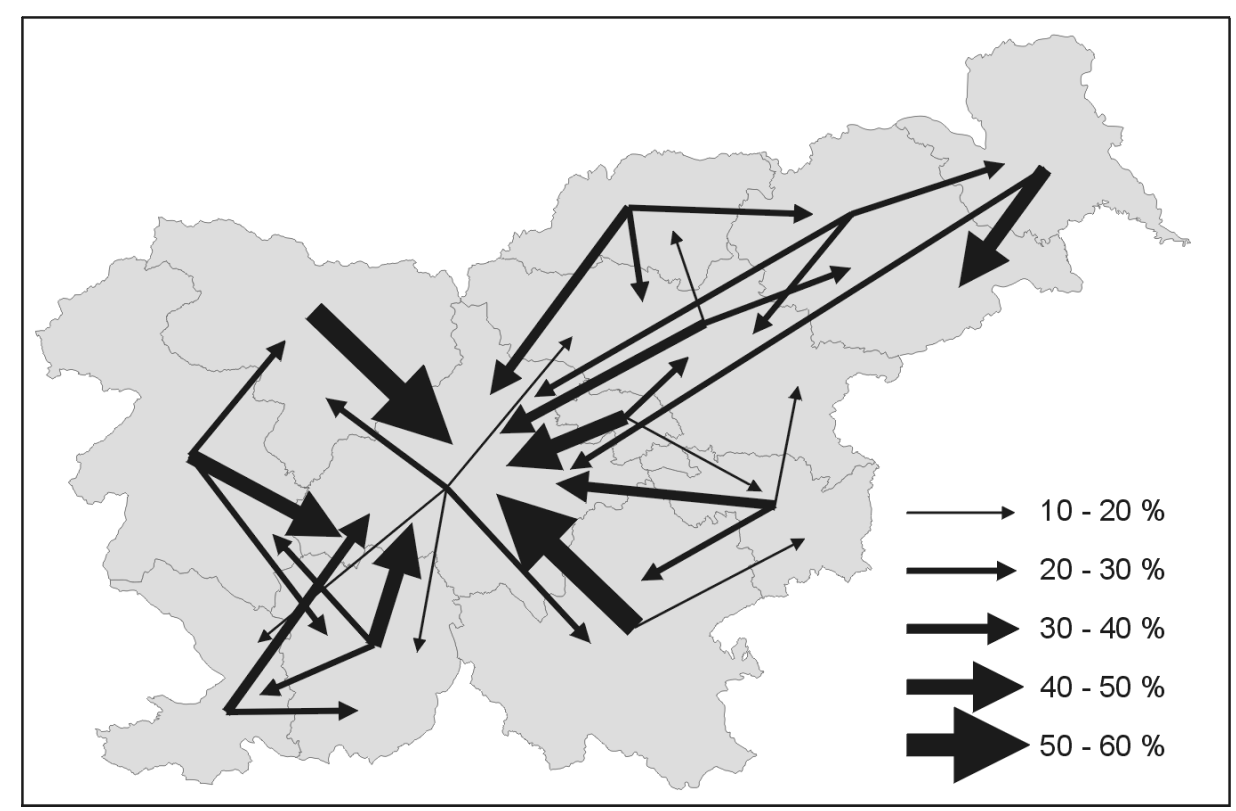

Vir: SURS

Osnovna naloga gospodarske politike je izboljšati učinkovitost in konkurenčnost gospodarstva $\mathrm{v}$ posameznih slovenskih pokrajinah.Ali drugače povedano, katere sintezne kazalce ekonomskega razvoja uporabiti, da se bo zagotovila ustrezna pokrajinska organiziranost Slovenije. Pokrajino je potrebno opredeliti kot samostojno prostorsko enoto, ki bo zagotavljala pospeševanje gospodarstva in bo izkoristila produktivno moč posamezne regije.

\section{POSPEŠEVANJE GOSPODARSTVA ZAGOTAVLJA REGIONALNI RAZVOJ}

Konkurenca na enotnem evropskem trgu je ena od gonilnih sil prostorskega razvoja Evropske unije. Čeprav so regije, mesta in lokalne skupnosti pričeli sodelovati na različnih področjih, že tekmujejo med seboj za gospodarske dejavnosti, delovna mesta in infrastrukturo. Vendar vse evropske regije nimajo 
podobnih izhodiščnih točk. Zaradi tega se zapleta pri krepitvi gospodarskega in družbenega povezovanja Evropske unije. Zato je tudi pomembno, da bi poskusili postopoma doseči prostorsko ravnotežje z namenom zagotoviti bolj enakomerno geografsko porazdelitev rasti na celotnem ozemlju Evropske unije (stremljenje h kohezivnosti). Nujna je primerljivost kazalcev razvitosti. Poleg klasičnih kazalcev razvitosti postajajo vedno pomembnejši sintezni kazalci: bruto domači proizvod na prebivalca po kupni moči, indeks človekovega razvoja, indeks uravnoteženosti razvoja, indeks nacionalne konkurenčnosti in indeks regionalnega razvoja (Slika 6).

Slika 6: Sintezni indikatorji razvoja

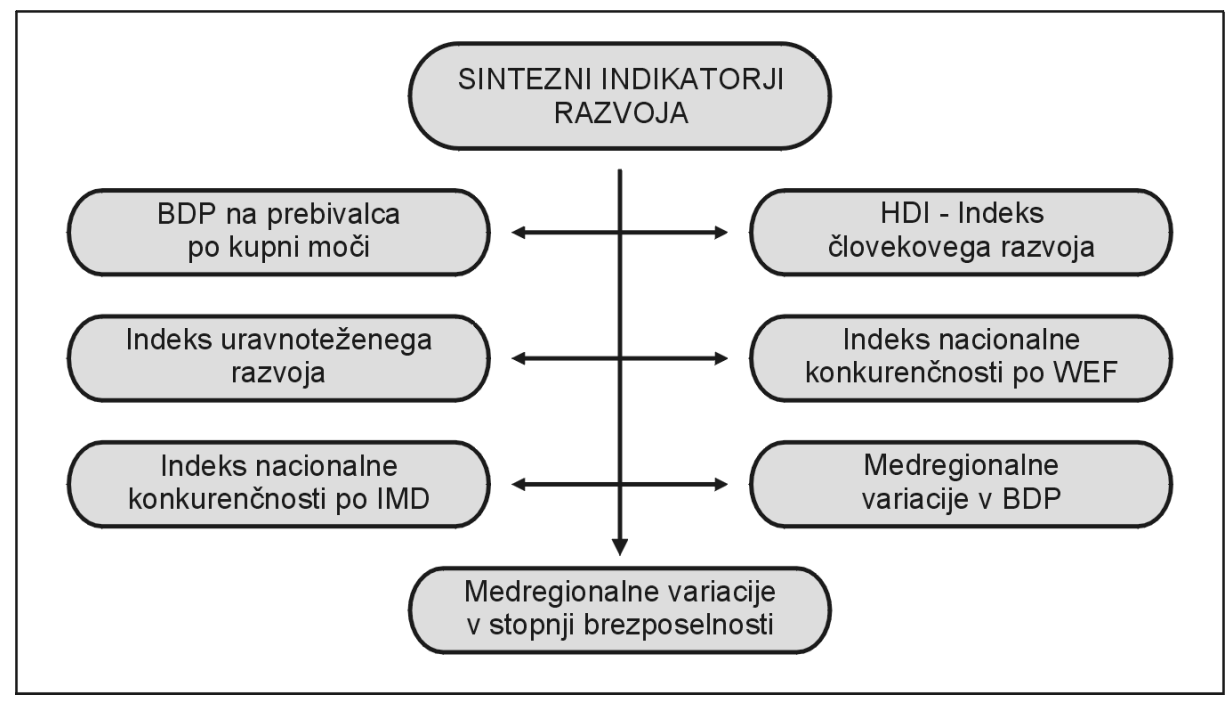

Ustvariti je potrebno pogoje za višjo gospodarsko rast, ki bi nas približala ravni ekonomske razvitosti Evrope. To pomeni, da mora Slovenija pospešeno obvladovati notranji trg Evropske unije in istočasno trajno razvijati potenciale naših podjetij na ravni splošnih razvojnih tendenc, ki potekajo v deželah Evropske unije, naših glavnih zunanjetrgovinskih partnerjev. Gre predvsem za krepitev investicij v sodobno opremo in tehnologijo, vlaganja v človeški kapital, obvladovanje mikrorazvojnih potencialov, tehnološko zahtevnejših programov in ustvarjanje višje dodane vrednosti na zaposlenega.

Ključni cilji strategije gospodarskega razvoja Slovenije so:

- hitrejša gospodarska rast na konceptu trajnostnega razvoja,

- povečanje konkurenčnosti nacionalnega in regionalnega gospodarstva, 
- vključevanje v EU,

- uravnotežen razvoj posameznih ekonomsko - geografskih območij države.

Sodobne faza v razvoju tehnologije oziroma »nova ekonomija«, daje regijam posebno priložnost, ki jo tradicionalni industrijski razvoj ni poznal. Nova ekonomija namreč odpira vrata $\mathrm{v}$ novi svet, ki spreminja naravo in organizacijo poslovanja, način vodenja in upravljanja, vzorce ekonomske politike in sistem vrednot. Sodobne oblike elektronskega poslovanja ustvarjajo nova delovna mesta in razmerja na trgu, ki so neodvisna od časa in geografskega prostora. Tradicionalni dejavniki proizvodnje - kapital, delo, zemlja - so relativno vse manj pomembni v primerjavi z znanjem, ki postaja ključni vir ekonomskega razvoja.

V naslednjih letih pričakujemo, da bo visoko avtomatizirana industrija ustvarjala glavnino proizvodnje $\mathrm{v}$ konvencionalnih panogah. Vendar se bo njen delež v izvozu zmanjševal, $\mathrm{v}$ gospodarstvu bo prevladovala storitvena dejavnost vseh vrst. Prodaja tujini bo predstavljala dominanten delež v bruto domačem proizvodu, to pomeni, da bo povečanje konkurenčne sposobnosti naših podjetij neposredno odvisno od izgradnje nove tehnološke in informacijske baze, ki je v središču nove ekonomije.

V Sloveniji je izredno neugodno razmerje med vlaganji v infrastrukturno »standardno" opremo, gradbeništvo, razne socialne projekte in subvencije ter vlaganji v sodobno tehnologijo ter krepitev znanja in razširitev produktivnih zmogljivosti človeškega kapitala. Slovenija še vedno namenja velik delež investicij projektom, ki neposredno ne povečujejo njene konkurenčne sposobnosti in ne krepijo razvojne potenciale države. Tako npr. industrija zagotavlja okrog $80 \%$ izvoza, pripada pa ji samo $20 \%$ celotnih naložb. Takšna naložbena dejavnost ne more zagotoviti prenavljanja proizvodnih programov ter povečanja dodane vrednosti na zaposlenega, kar je osnovni kriterij konkurenčne sposobnosti majhnega odprtega gospodarstva ( Savin, D., 2001).

Po podatkih World Bank, ima v strukturi celotnega kapitala, definiranega kot proizvodni kapital, največji delež človeški kapital (Human Capital): okrog $64 \%$, naravna bogastva $20 \%$ in finančni kapital $16 \%$. Človeški kapital, tj. znanje in usposobljenost upravljanja s produkcijskimi procesi, je dosegel tako velik delež, zahvaljujoč stalnemu vlaganju $\mathrm{v}$ to obliko kapitala. Ta dosega $\mathrm{v}$ visoko razvitih družbah več kot $10 \%$ BDP, v zmerno razvitih družbah pa med $6 \%$ in $10 \%$ BDP (v Sloveniji 8,5\%). Mednarodne institucije postavljajo prav vlaganja $\mathrm{v}$ razvoj človeškega kapitala za primarni dejavnik regionalnega razvoja v svetu, tako razvitem kakor tudi v nerazvitem.

Vključevanje univerz in njihovo povezovanje lahko vpliva na učinkovitejše povezovanje znanja, tehnologije in zagotavlja tehnološki razvoj ter prenos znanja $v$ posamezne regije. Zagotavljanje mobilnosti raziskovalcev in študen- 
tov, zaposljivosti diplomantov glede na kvaliteto njihovega znanja in kreativnosti, vlaganja $\mathrm{v}$ znanje in razvoj bo pomenilo uspešni ekonomski regionalni razvoj, ki bo zagotovil socialno stabilnost in bo hkrati ohranil ter vzpodbujal kulturno pestrost evropskih narodov (Lorber, L.,2001) (Slika 7).

Slika 7: Vpliv univerze v regionalnem razvoju

UNIVERZA

\section{VLOGA GEOGRAFIJE PRI ZAGOTAVLJANJU URAVNOTEŽENEGA IN TRAJNOSTNEGA RAZVOJA}

Družbeno - geografske procese posamezne regije lahko vrednotimo le v primerjavi s primerljivimi regijami in državnim povprečjem. Ker so razvojni procesi integralni, jih lahko razumemo in evalviramo le $\mathrm{z}$ interdisciplinarnim pristopom. Čeprav je ključna značilnost geografske vede njena kompleksnost v proučevanju prostora, potrebuje za analizo celostne problematike tudi vedenja drugih znanstvenih disciplin in različnih strok.

Podpora razvoju interdisciplinarnih temeljnih, aplikativnih in razvojnih raziskav, ki vključujejo področja tehnologije, naravoslovja, družboslovja in humanistike terjajo od geografov večje aktivno vključevanje. Na ta način bi pripomogli $\mathrm{k}$ vzpostavitvi celostnega pristopa $\mathrm{k}$ pospeševanju skladnega regionalnega razvoja.

Vse stroke, ki so odgovorne za prostorski razvoj naj bi upoštevale prednostne prostorske razvojne cilje, ki jih je definirala Evropska skupnost. V 
skladu z opredelitvijo, določeno v Brutlandovem poročilu Združenih narodov, trajnostni razvoj ne vključuje le okoljsko upravičenega in smotrnega gospodarskega razvoja, ki ohranja sedanje vire za prihodnje generacije, temveč tudi uravnotežen socio - ekonomski prostorski razvoj. To pomeni, še zlasti usklajevati družbene in gospodarske zahteve po namenski rabi prostora z ekološkimi in kulturnimi funkcijami območja in s tem prispevati k trajnostnemu prostorskemu razvoju, ki je uravnotežen na regionalni ravni.

Prostorsko urejanje mora upoštevati dejstvo, da najrazličnejše dejavnosti $\mathrm{v}$ gospodarstvu in negospodarstvu vplivajo na razvoj v prostoru. Ozka gledanja na prostorsko planiranje imajo lahko dolgoročno zelo negativne posledice. Prostorsko načrtovanje bo doseglo svoj cilj le v primeru, da bo znalo na smotrn način vključevati širša načela za usmerjanje razvoja v prostoru in v družbi nasploh (Gosar, L., 2001).

$\mathrm{Z}$ analiziranjem in stalnim raziskovanjem procesov $\mathrm{v}$ prostoru bo omogočeno permanentno pripravljanje aktualnih, problemsko usmerjenih osnov, ki bo javnim in zasebnim nosilcem pomagala do regionalnih učinkovitih odločitev.

Univerza v Mariboru je ustanovila Znanstveni inštitut za regionalni razvoj kot instrument regionalnega razvoja in regionalne politike, posebej še $\mathrm{v}$ podporo razvoju strukturno šibkih regij. Ob upoštevanju deleža študentov, števila zaposlenih na univerzi, občutnega deleža dohodka pri mestnih storitvah, deleža v celotnem dohodku lokalnega gospodarstva, investicijska vlaganja, prenos znanja in informacij lahko rečemo, da je univerza prevzela aktivno vlogo partnerja v regionalnem razvoju (Razvojni program Univerze v Mariboru 1998 - 2003, 1999).

Osnovni cilj inštituta je oblikovati regionalne zasnove, ki bodo omogočile posameznim slovenskim regijam, ki so obremenjene s svojimi specifičnimi potenciali in problemi, doseči lasten regionalni razvoj. Za dinamični razvoj nacionalnega gospodarstva pomeni razvojno zaostajanje ene, ekonomsko zaostajanje celotne države.

$\mathrm{Z}$ interdisciplinarnim pristopom $\mathrm{k}$ znanstveno- raziskovalnemu delu bo omogočeno sodelovanje in povezovanje raziskovalcev različnih znanstvenih področij. Povečanje sodelovanja med raziskovalnimi institucijami na nacionalni in mednarodni ravni bo zagotavljalo večje učinke za dosego uravnoteženega in trajnostnega razvoja.

\section{Viri in literatura:}

Državni razvojni program R Slovenije 2001 - 2006 (predlog), 2001, Ministrstvo za gospodarstvo, Ljubljana.

European Spatial development Perspective, 1999, EU Commission, Potsdam. 
Gosar, L., 2001: Metoda izdelave razvojnega programa, Geografski vestnik, Zveza geografskih društev Slovenije, Ljubljana.

Lorber, L.,1999: Procesi prestrukturiranja mariborske industrije in njihov vpliv na transformacijo prostora. Doktorska naloga, PMF, Zagreb.

Lorber, L.,2000: Promet kao čimbenik regionalnog povezivanja Maribora. Suvremeni promet, Zagreb.

Lorber, L.,2001: The Importance of Inter University Links in the Process of Formation and Development of European Regions. MER, Maribor.

Lorber, L., Pašič, Z.,2000: Znanstveni inštitut za regionalni inštitut pri Univerzi v Mariboru. Univerza v Mariboru, Maribor.

Mali, F.,1995: Aplikacija znanosti in prenos znanja $\mathrm{v}$ industrijo. Raziskovalec,št.3, letnik XXV, Ljubljana.

Maier, J., 2001: Neue Grenzraumforschung unter besonderer Bedeutung men taler Strukturen - das Beispiel der bayerisch - bohmischen Grenze, Obmejna območja, Pedagoška fakulteta, Maribor.

Pravilnik o infrastrukturnih raziskovalnih centrih, 1994, MZT, Ur.l. RS, št. 68.

Razvojni program Univerze v Mariboru 1998 - 2003, 1999, Univerzitetne novice, Maribor

Ruppert, K.,1998: Evropska zasnova razvoja prostora, Institut fuer Wirtschaftsgeographie.

Savin, D., 2001: Dinamiziranje gospodarstva Slovenije v procesu prilagajanja EU s poudarkom na regionalnem razvoju. CIMRS - ZIRRUM, Maribor.

Spletne strani in publikacije Statističnega urada R Slovenije.

Zakon o pokrajinah (delovno gradivo), 2001, Vlada RS.

\section{THE ROLE OF GEOGRAPHY IN INTERDISCIPLINARY PLANNING OF REGIONAL DEVELOPMENT}

\section{Summary}

The interweaving of processes, which are dictated by globalisation of the world encroach into all spheres of man's life and creations and create new relations between space units. Economic development enables inclusion in modern integration processes and the development of individual regions. During the last few years, global economic links, technological development and political changes have triggered changes also in the European space structures (Maier, J., 2001). Ever stronger European integration dictated the formation of a vision on the European space as a whole. In contrast to the tendency of centralism an emphasised need developed for regional space organisation of 
Europe as a model of decentralisation or polycentric development model respectively. Emphasizing regional diversity, consciousness of the non-exchangeable identities of culture, people and space, socio-economic peculiarities has become the positive orientation for the new formation of space structures (Ruppert, K., 1998).

Taking into consideration social, cultural, political and environmental characteristics of individual regions regional development depends on dynamism of the economy. Reconciliation of activity in economics and non-economics has an impact on development success and productivity power in defined regions and assures development durability.

Restructuring economy processes characteristic for post-industrial periods have an impact on the transformation of space and new development paradigms. They change the comprehension of geographical space and elements, which define a region as a space unit.

The basic goal of Slovene regional policy is to achieve balanced economic, social and environmental development of the Slovene space. This is the condition for equal inclusion of Slovenia in the European Union. The process of globalisation reduces national differences in competitiveness and sets the role of regions in an equivalent position with the State. The forming of an integrated European space is expressed in the changes of functional regions and gravitational strength as employment centres. Especially the development potential of individual regions determine common interests for collaboration and how to form a creative milieu, which will assure growth and quality life for future development.

Social - geographic processes of individual regions can be assessed only in comparison with comparable regions and state averages. Planning regional development in changed socio-economic conditions is mainly in cooperation with the remaining regions by assuring accordant and durable development.

Strengthening structurally weak European Union border regions, and improving cross-border life and working conditions in regions that have different levels of development represent a big challenge. It is necessary to adjust the development targets, equilibrium and security. Policy, oriented exclusively on equilibrium would lead to weakening the economically stronger regions and simultaneously increase the dependency of less successful ones. Development itself would give precedence to growing regional discord. On the other hand too great an emphasis on preserving the existing situation brings the risk of stagnation, because with that perhaps the development trend would slow down.

The role and significance of geography in planning regional development in changed social - economic conditions is in cooperation with the remaining scientific disciplines in assuring comformable regional development. 